Images in...

\title{
Delayed tendon reflex (a video demonstration)
}

\author{
Arjun Maitra, ${ }^{1}$ Madhav Basal, ${ }^{2}$ Anil Kapoor, ${ }^{3}$ Rakesh Biswas ${ }^{3}$
}

${ }^{1}$ Department of Physiology, People's College of Medical Sciences, Bhopal, India

${ }^{2}$ Department of Community Medicine, People's College of Medical Sciences, Bhopal, India

${ }^{3}$ Department of Medicine, People's College of Medical Sciences, Bhopal, India

Correspondence to Rakesh Biswas, rakesh7biswas@gmail.com

\section{DESCRIPTION}

A 50-year-old woman who was a homemaker presented to us with a history of gradual weight gain over the last 3 years, and on examination was found to have a puffy face (figure 1) along with marked coarsening of her skin (figure 2). On neurological examination the most remarkable finding was a delayed tendon reflex prominent in the biceps and tendo Achilles (video 1).

Video 1 Delayed tendon reflex prominent in biceps and tendo Achilles. 10.1136/bcr.04.2009.1797v1

This was a classical presentation and the diagnosis was obvious.
Her thyroid hormone profile revealed a thyroidstimulating hormone level of $151.79 \mu \mathrm{IU}$ (normal 0.35-5.50) along with a total T3 of $0.31 \mathrm{ng} / \mathrm{ml}$ (normal 0.60-1.81) and total T4 of 1.00 (normal 5.60-13.70).

In an excellent review of the delayed tendon reflex it has been shown that the rate of muscle relaxation depends on the rate of calcium reaccumulation in the endoplasmic reticulum, and this rate is slowed in hypothyroidism. ${ }^{12}$

However, the caveat is that there are various reasons identified that can cause a delayed ankle relaxation such as diabetes mellitus, chorea, advanced age, anorexia nervosa, pregnancy and even peripheral oedema, ${ }^{13}$ and the diagnosis of hypothyroidism has to be based on other clinical features and laboratory confirmation as in our patient.

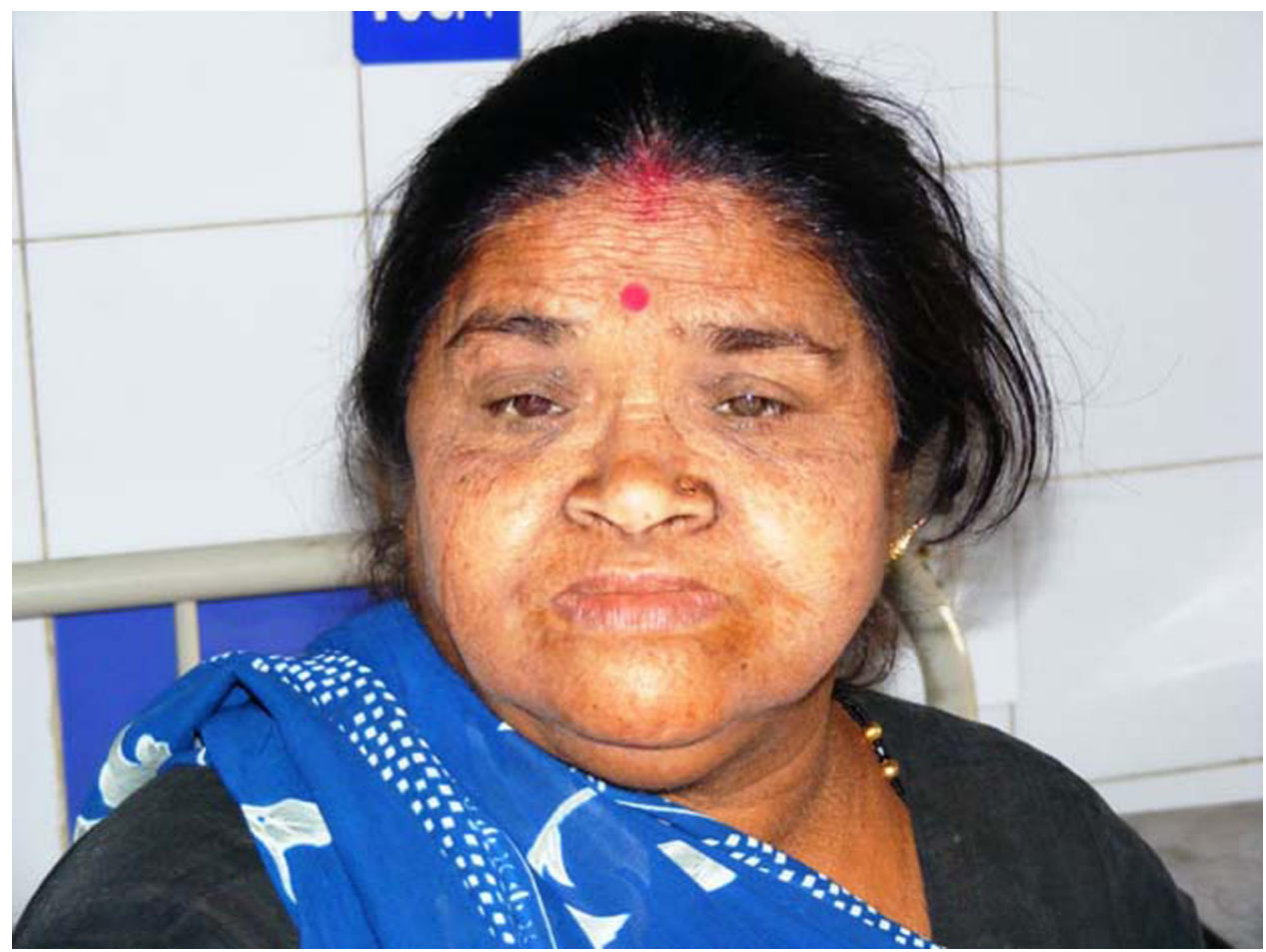

Figure 1 Facial puffiness. 


\section{BMJ Case Reports}

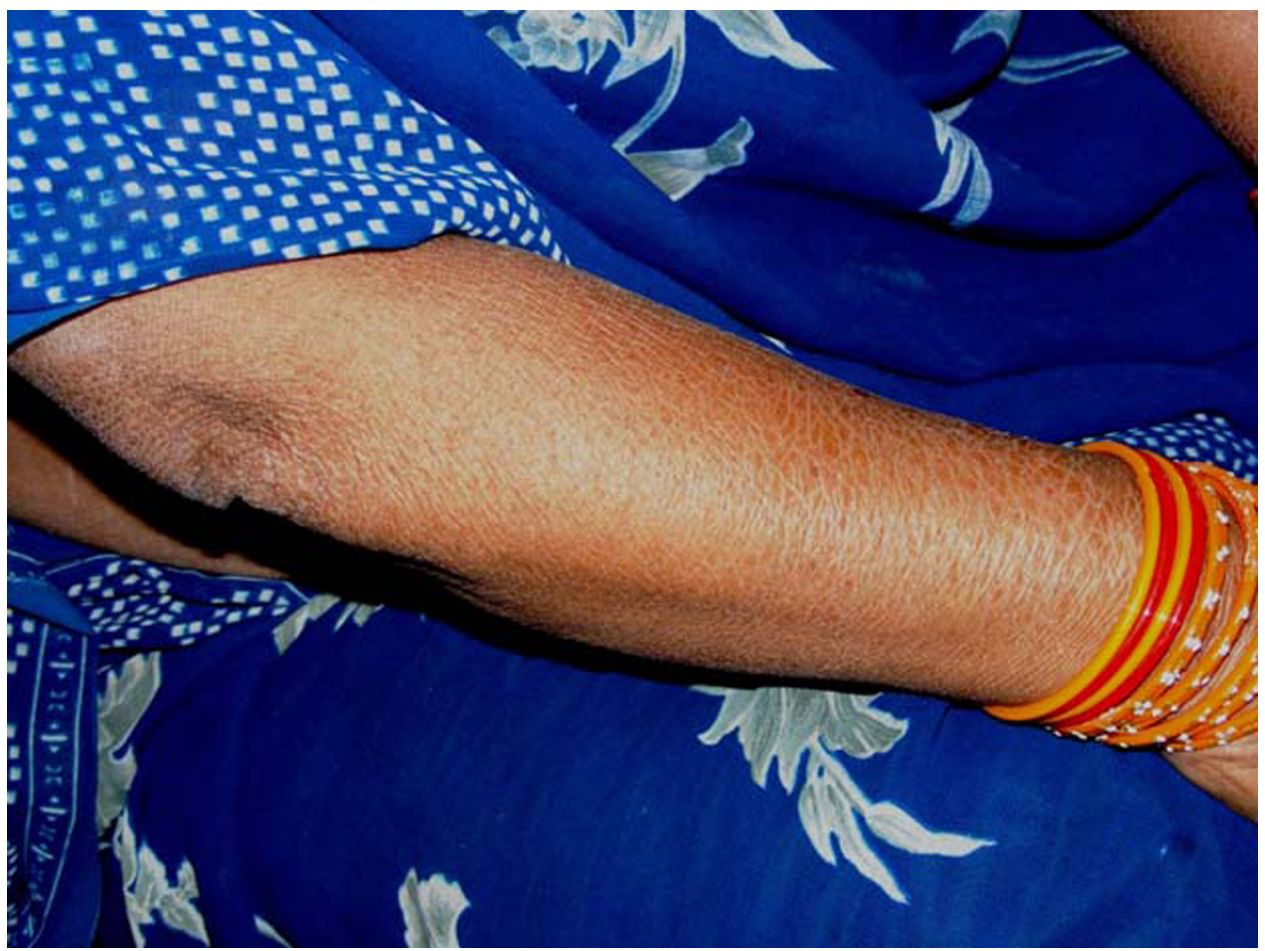

Figure 2 Skin coarsening.

Acknowledgements We acknowledge all who cared for this patient.

Competing interests None.

Patient consent Obtained.

\section{REFERENCES}

1. Marinella MA. Woltman's Sign of hypothyroidism. Hospital Physician January 2004:31-2.

2. Ianuzzo D, Patel $P$, Chen $V$, et al. Thyroid tropical influence on skeletal muscle myosin. Nature 1977;270:74-6.

3. The metabolic myopathies. In: Adams RD, Victor M, eds. Principles of neurology. 4th edn. New York: McGraw-Hill, 1989:1133-9.

This pdf has been created automatically from the final edited text and images.

Copyright 2010 BMJ Publishing Group. All rights reserved. For permission to reuse any of this content visit http://group.bmj.com/group/rights-licensing/permissions.

BMJ Case Report Fellows may re-use this article for personal use and teaching without any further permission.

Please cite this article as follows (you will need to access the article online to obtain the date of publication).

Maitra A, Basal M, Kapoor A, Biswas R. Delayed tendon reflex (a video demonstration). BMJ Case Reports 2010;10.1136/bcr.04.2009.1797, date of publication

Become a Fellow of BMJ Case Reports today and you can:

- Submit as many cases as you like

- Enjoy fast sympathetic peer review and rapid publication of accepted articles

- Access all the published articles

- Re-use any of the published material for personal use and teaching without further permission

For information on Institutional Fellowships contact consortiasales@bmjgroup.com

Visit casereports.bmj.com for more articles like this and to become a Fellow 